\begin{tabular}{c} 
Volume and Issues Obtainable at Center for Sustainability Research and Consultancy \\
Journal of Business and Social Review in Emerging Economies \\
ISSN: 2519-089X (E): 2519-0326 \\
Volume 7: No. 1, March 2021 \\
CSRᄃ \\
Journal homepage: www.publishing.globalcsrc.org/jbsee \\
\hline
\end{tabular}

\title{
Impact of Communication Climate on Conflict Management Styles among Employees
}

\author{
${ }^{1}$ Nazia Jahangir, ${ }^{2}$ Aasima Safdar, ${ }^{3}$ Beenish Zaheen \\ ${ }^{1}$ Lecturer, Department of Psychology, Institute of Southern Punjab, Multan, Pakistan, \\ naziajahangir4@gmail.com \\ ${ }^{2}$ Assistant Professor, Department of Communication Studies, Bahauddin Zakariyah University, \\ Multan, Pakistan, aasima.2014@gmail.com \\ ${ }^{3}$ Lecturer, Department of Mass Communication, the Women University, Multan, Pakistan

\begin{tabular}{l}
\hline RTICLE DETAILS \\
\hline History \\
Revised format: February \\
2021 \\
Available Online: March \\
2021
\end{tabular} \\ JEL Classification \\ M10, M14

\section{ABSTRACT} \\ The quality of the relationship between people manifested by spoken \\ and wordless messages refers to the communication climate. The \\ approach of people about how to feel about each other generates the \\ communication climate. When people perceive they are desirable so \\ it builds the productive communication climate. A negative climate \\ makes it difficult for people, because it is hard to communicate. The \\ purpose of present study is to find out impact of communication \\ climate on conflict management styles among employees. The \\ sample was consisted on $\mathrm{N}=295 \mathrm{employees}$ calculate by using $\mathrm{G}$ - \\ power method. Employees were taken from different organizations of \\ Multan .Communication Climate Inventory and Rahim \\ Organizational conflict inventory were used to collect the data. The \\ result shows that integrating and obliging styles of handling conflict \\ are significantly correlated with supportive communication climate. \\ The result also shows that dominating and avoiding styles are \\ significantly correlated with Defensive communication climate. \\ There is a significant impact of communication climate on conflict \\ management styles among employees. \\ (C) 2021 Center for Sustainability Research and Consultancy Pakistan under \\ a Creative Commons Attribution-NonCommercial-ShareAlike 4.0 \\ Corresponding author's email address: naziajahangir4@ gmail.com \\ Recommended citation: Jahangir, N., Safdar, A. \& Zaheen, B. (2021). Impact of Communication \\ Climate on Conflict Management Styles among Employees. Journal of Business and Social Review in \\ Emerging Economies, 7(1), 63-68

\section{Introduction} \\ Communication plays a central role in any organization setting and it is directly related to the study of \\ employees' interaction with other employees at working environment. Every person conveys their \\ thoughts, ideas and feeling through communication. So the employees' position and function within the \\ organization are likely to affect the structure and content of their communication.(Hackman, Michael Z., \\ and Craig E. Johnson.2000).
}


Spoken and wordless messages which are sent, received and understandable are conveyed by affection and plans of responsive, senseless, purposeful and involuntary communication process '(Guzley,1992). Verbal communication is a course of action in which people express their ideas through words and can transfer and spread any type of information face to face. It makes a person capable to make better connections and association with people. Putnam (1985) define communication climate as "the atmosphere in an organization regarding accepted communication behavior. "Usually use supportive and defensive communication climate as distinction for the key factors in the communication climate (William.J.2001).

A person may feel encouraging and protective by communication if the climate is non-judgmental. So the open, useful, truthful and successful communication with people stimulated by supportive climate. A person makes himself protective which guides him towards aggressive and harmful disputes defined by defensive communication. So the encouraging communication climate sustain by adequate communicators who strive for it.. According to Dr. Gibb (1961) describes six dimension of behavior to warm up or chill the communication climate. The pole of these dimensions creates a defensive climate and supportive climate. They applied equally in every small group.

Organizational climate has been confirmed between members of an organization as an evaluative element (Guzley, 1989). A productive organization is generated by one of the most progressive element i.e organization communication climate which is different from organizational climate in literature (Zaremba, 2003). Communication climate is different from organizational environment and climate. It can be describe through the effective communication techniques using by the employees in the organization. When employees avoid to sort out their conflicts with others they can used defensive communication style (Poole, 1985). The formation of the communication climate of the organization is the central duty of the management.

A team can work in highly systematic manner by an important factor which is a satisfying working atmosphere; the enthusiasm of an employee enhanced by positive communication climate which played consequential role in it. So it depends on manager to use his expertise in order to maintain and generate positive communication climate and use it in their work to get inventive attainment in a well organized and easy manner and the manager will be able to recognize the behavior is coherent or not and change it accordingly. The organization's decision-making and accomplishment of task is easy in positive communication climate and it can also provide the even movement of information to the campaign. So, all the organizations will attain a good communication environment if they remove the barriers inhibited and completely well-inform about the significance of positive communication (Taguiri, R.1968) Conflict is classified into the following types; Interpersonal conflict refers to a conflict between two people. This happens usually thanks to however individuals are completely different from each other. Apparently, it's a natural incidence which may eventually facilitate personal growth or developing your relationships with others Intrapersonal conflict happens inside a person. (Akinsaya, A.O. and Momoh, A.M.2012).

The expertise takes place within the person's mind. Hence, it's a kind of conflict that's psychological involving the individual's thoughts, values, principles, and emotions. Intergroup conflict; could be a sort of conflict that happens among people inside a team. The incompatibilities associated misunderstandings among these people cause internal conflict. It is arising from social disagreement (e.g. team members have completely different personalities which can cause tension) (Evans, 2013).Conflict between people is a fact of life. It is inherent in all social life. Its occur when an individual or a group feels negatively affected by another individual or a group. Conflict as the internal state that results from difference in ideas and feeling among different people.(Marquis.T\&Huston.R,1996).

\section{Literature Review}

A research conducted by Shahrina et al., (2014). The study describe that when personnel used different types of strategies to avoid conflict at the workplace ,So positive and supportive communication is help 
out them to deal and manage their conflict in the organization. The findings discuss the impact of various communicative strategies used in conflict management on the organizational communication climate. The results suggest that conflicts are always play important role in the organization. The management of the organization or leaders has used different approaches to identify the conflict between the employees. By using effective communication during conversation is sort out the problems among top management and employees. Performance of the employees is depend on the environment and climate in the organization.

A research conducted by Bushra Hassan and AneelaMaqsood and Muhammad Naveed Riaz on "Relationship between Organizational communication climate and Interpersonal conflict management" in (2011). This study examined the Relation between different styles of interpersonal conflict management and dimensions of organizational communication climate were looked into, employing a sample of 160 bank employees. Sample included men and women employees having age range of 27 to 55 years and education ranges from graduation to post graduation. The correlation analysis revealed that supportive and defensive communication climate dimensions showed positive relationship with total scores of conflict management inventory. The results further showed that integrating, obliging and compromising styles of handling conflict has significant positive correlation with supportive communication climate. Dominating and avoiding styles of handling conflict has significant positive correlation with defensive communication climate. Findings revealed non significant differences with respect to gender on communication climate women are found to use more "comprising" and "avoiding" styles of conflict management. On education non significant differences existed on communication climate however less educated people were found to be compromising and obliging on styles of conflict management and highly educated people showed dominating styles of conflict management. Moreover, younger employees are found to be highly endorsed on supportive communication climate than old age employees and old age employees are also found to be more obliging.

A research conducted by Ojo Olu and Abolade on "how conflict management impact on employees' performance. The research findings show that organization used conflict management styles to enhance employee's performance in an organization. It was responsibility of the organization should design on training and retraining of its employees in area of dealing with conflict so as to create a productive working environment for the employees and that there should be used supportive communication between and among all of the management, staff and employees in the organization. This will deal and sort out conflicting situations in the organization. The employees must be trained and discourage by using defensive communication climate when they are dealing or manage their conflicts.

A research conducted by Reza Hosseinpour and Giti Pahlevani (2016) on communication and dealing with conflict. This study explores the correlation between styles of conflict management and teachers' organizational health in Kuhdasht County. This study is a descriptive-survey and correlational-type research. The statistical population is consisted of all 431 teachers working in Kuhdasht County. Using Krejcie-Morgan table, the sample size is determined to be 205; the sample members have been selected using relative stratified random sampling method. In order to collect the required data Allen \& Meyer Organizational Commitment Questionnaire and Miles Organizational Health Questionnaire have been used. In order to analyze the data descriptive statistics indices such as the mean and standard deviation as well as inferential statistics tests such as Pearson's correlation test and multivariate regression have been used. The results suggest that avoiding, collaborating, accommodating, and compromising styles of conflict management have a positive and significant relationship with organizational health.

\section{Hypotheses of the study}

1. There would be a significant impact of Communication climate on conflict management styles among employees.

2. There would be a relationship between communication climate and conflict management styles? 
3. The employees will score high on supportive climate will also score high on Integrating and obliging styles?

4. The employees will score high on defensive climate will also score high on dominating and avoiding styles?

\section{Research Framework}

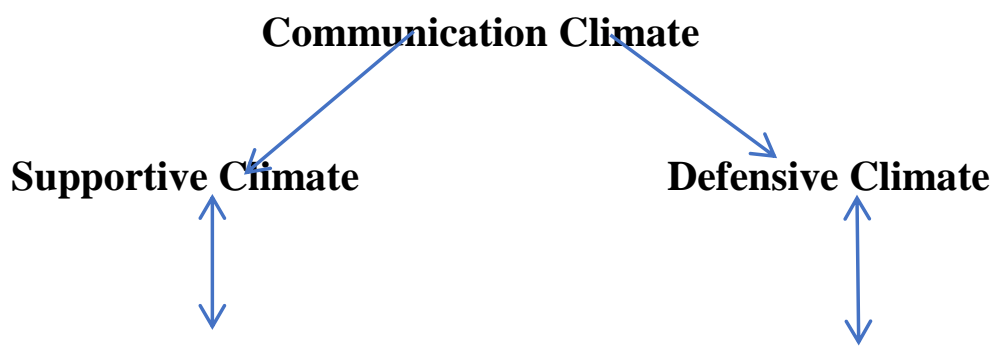

Obliging \& Integrating Conflict Styles

Dominating \& Avoiding conflict Styles

Source: Researcher

\section{Method}

The present study is the sample was consisted of $(\mathrm{N}=295)$ employees were taken from different organizations of Multan. The Random sampling technique was used to the collect data. The age range was being from 25-45 years. Along with instruments, a demographical variable sheet was being attached to measure the demographical variables (Age, Education, experience, income).Two research instruments were used to collect data. Communication climate inventory developed by Schmiedler \&Costigen(2001). The Inventory consisted on 36 items scale, each item score on 5-point scale. Internal reliability ranged from .80 .Out of 36 items the odd numbers of items measure the defensive climate and even number of items measures the supportive climate. How organizational members manage their interpersonal disputes with superiors, subordinates and peers measure by Rahim Organizational Conflict Inventory (ROCI-11, Rahim, 1983). Conflict management styles are assessed by 28-items. The inventory contains five subscales. Integrating (7items), obliging (6item), dominating (5 items), avoiding (6items), and compromising 94item).The instrument measure how an organizational member handles his or her conflict with superiors, subordinates, and peers. Internal reliability ranged from 60 to 83. An organizational member responds to each statement on a five-point scale $(1=\mathrm{N})$ never or almost never true of you, $(2=\mathrm{R})$ rarely or seldom true of you, $(3=\mathrm{S})$ sometimes true of you, $(4=\mathrm{O})$ often true of you, $(5=\mathrm{A})$ always or almost true of you. A higher score represents greater use of conflict style.

\section{Results}

Table-1Alpha Reliability Coefficient of ROCI and CCI ( $\mathrm{N}=295)$

\begin{tabular}{lcc}
\hline \multicolumn{1}{c}{ Scales } & No of Items & Cronbach s Alpha \\
\hline Communication Climate Inventory & 36 & 0.80 \\
Rahim Organizational Conflict Inventory & 28 & 0.71 \\
\hline
\end{tabular}

Above table shows that Cronbach's alpha reliability of the scales.

Table-2 Regression Analysis showing Impact of Communication Climate on conflict management styles among Employees ( $\mathrm{N}=295)$

\begin{tabular}{llllll}
\hline Predictor & B & Std. Error & Beta & T & P \\
\hline $\begin{array}{l}\text { (constant) } \\
\begin{array}{l}\text { Communication } \\
\text { Climate }\end{array}\end{array}$ & .053 & .034 & .078 & 1.553 & .000 \\
\hline
\end{tabular}

Note. $\mathrm{R}=.078, \mathrm{R}^{2}=.006$, adjusted $\mathrm{R}^{2}=.004, \mathrm{~F}=2.412, \mathrm{P}<0.05$

Above table shos that there is a significant impact of communication climate on conflict management styles among employees. 
Table-3 Pearson Correlation between Supportive Communication Climate and conflict management styles among Employees ( $\mathrm{N}=295)$

\begin{tabular}{|c|c|c|}
\hline Scale & Obliging & Integrating $\mathbf{P}$ value \\
\hline Defensive Communication & $0.125 * *$ & $0.270 * *$ \\
\hline
\end{tabular}

** Correlation 0.01 (2-tailed).

In Above table the result shows that integrating and obliging styles of handling conflict are significantly correlated with supportive communication climate.

Table-4Pearson Correlation between Defensive Communication Climate and conflict management styles among Employees $(\mathrm{N}=295)$

\begin{tabular}{|c|c|c|c|}
\hline Scale & Dominating & Avoiding & $P$ value \\
\hline Defensive Communication & $0.165^{* * *}$ & $0.184 * *$ & 0000 \\
\hline
\end{tabular}

** $\mathrm{P}$-value is significant at (2-tailed).

The result also shows that dominating and avoiding styles are significantly correlated with defensive communication climate.

\section{Discussion}

This finding is in line with literature that there is a relationship between communication climate and interpersonal dispute administration styles.Hendel,Fish\&Galon,(2005),Trombetta \&Roger,(1988), Wei \& Morgan(1996) did studies and find out that For the usefulness and success of an organization, communication climate has a supreme importance in an organization. The organization's environment affected by the communication climate of an organization. On the other hand, energetic engagement, beneficial interchanges of information and positive disputes decision also inspired by organization with supportive environment. In an organization collaborative communication climate can be implant through productive administration of disputes. First Hypothesis is accepted that there is a significant impact of Communication climate on conflict management styles.

Communication climate is directly effect on conflict management styles. When climate is Supportive employees uses obliging and integrating styles by handling there conflict in the organization. Result find out that, in organization employees used dominating and avoiding conflict management styles, when communication climate is defensive there is no significant gender difference could find out in the context of gender. Pervious literature supports the findings of the present research.

\section{Conclusion}

Communication between the employees is very important to deal conflict and issues in the organization and communication climate create the supporting environment for working condition. For the Employees is to understand communication within an organization, it is important to explore that how the processes of communication is effect on the organizational climate and how the conflicts managed by the members through using communication. Communication climate describe through supportive and defensive climate. The result shows that there is a significant impact of Communication climate on Interpersonal Conflict styles. The implication of the study is very important in the context in the organization, that employee's batter understand the importance of communication climate and identify that conflict management styles. Conflicts within the organization between the employees is a very common thing, but if the conflict neither is nor proper handle by the organization management .It is directly affect the organization development and employees performance as well. The implementation of the current study is highly related with the employee understanding towards other persons. Conflict is part of everyday life. When a person working in an organization, difference of opinion is always occurs. Sometime is very productive but most of the time its effect on employees interpersonal relationship at work place .This research finding is help out to employees to use supportive climate in the conversation with others employees. 


\section{References}

Akinsaya, A.O. and Momoh, A.M. (2012).University Organizational Communication Climate and Management of Industrial Conflict. JORIND 10 (2):171-174.

Evans, B.(2010).Life resistance: Towards a different concept of the political. Deleuze Studies, 4(supplement), 142-162.

Gibb,G.R.(1966)Defensive communication climate. Journal of communication, 9(3)141-148.

Guzley, R. M. (1989). Tenure, socialization, and perceived supervisory interaction as indicators or organizational commitment. Paper presented at the meeting of the Speech Communication Association, San Francisco.

Guzley, R.M. (1992). Organizational Climate and Communication Climate: Predictors of Commitment to the Organization. Management Communication Climate Quarterly, 5(379):379-402.

Hendle,T.,Fish,M.\&Galon,V.(1996)Leadership style and choice of strategy in conflict management. Journal of conflict management, 10 (4),25-30.

Hackman, Michael Z., and Craig E. Johnson.(2000) Leadership: A Communication Perspective. Waveland Press. Print.

Jablin, L.L. Putnam, K.H. Roberts, \&L.W. Porter (Eds.) Handbook of organizational communication: An interdisciplinary perspective (pp.195-227). Newbury Park: Sage.

Marquis,B.K.\& Huston,C.J.(1996)Leadership roles and managers function in nursing. Philadelphia: Lippicincott.

Miller, K. (2006). Organizational Communication: Approaches and Processes. USA: Thomson Wordsworth.

Putnam,L.(1985).Communication and interpersonal conflict in the organization. Management communication Quarterly,1,293-301.

Poole, M.S., \& McPhee, R.D. (1983). A structural analysis of organizational climate. In L.L.

Schmeidler,M.A,Costigen,J.I,(2001).OrganizationalCommunicationOB321SupplementaryMaterials:Co mmunicationClimateInventory.Retrievedfrom,www.cps.usfca.edu/ob/sudenthandbomnk/climate. htm.

Taguiri, R. (1968). The Concepts of Organizational Climate, in R. Taguiri and G.H. Litwin (editors), Organizational Climate: Exploration of a Concept, Boston: Harvard University Press.

Trombetta, J.J. \& Rogers, D.P.(1988)Communication climate, job satisfaction and organizational commitment. Management Communication Quarterly, 1:494-514.

Wei,L. \& Morgan,D.(2004).Supportiveness of organization climate. Journal of Product innovation Management,21(6),375-380.

William J. Buchholz (2001). Open communication climate. Bentley College Waltham, Massachusetts.

Zaremba, A.J. (2003). Organizational Communication. Canada: Thomson Learning

Shahrina, M.N., Subarna, S., Ena, B., Wan Fatima, W.A. (2014) Organizational Communication Climate and Conflict Management: Communications Management in an Oil and Gas Company January 2014 Procedia - Social and Behavioral Sciences 109:1046-1058

Hassan, Bushra \& Maqsood, Aneela. (2012). Relationship between organizational communication climate and interpersonal conflict management. Pakistan journal of psychology. 42. 23-41..

Reza, H., Giti, P. (2016). The Relationship between Conflict Management Styles and Teachers' Organizational Health. International journal of Humanities and Cultural studies ISSN 23565926 